\title{
The scandals of covid-19
}

\author{
Kamran Abbasi executive editor
}

The BMJ

Last seen in public clapping on the doorstep of Number 10 Downing Street for the NHS while self isolating, the prime minister was in intensive care four days later (doi:10.1136/bmj. m1433). Covid19, the virus that is turning the world upside down, does not respect borders or political leanings (doi:10. 1136/bmj.m1336). It isn't a virus in some other place, sparing health systems in richer countries. Covid-19 is here and everywhere. And, through hubris, much of the world was scandalously unprepared.

In time, a chance will come to reshape our world, prioritise health and wellbeing, work as equal partners with Africa and Asia, and build international solidarity. The agendas of nationalism and isolationism (the ideologies that downgrade public health and primary care), and the selfishness that perpetuates inequalities and a climate disaster, are being destroyed by a pathogen spreading with the ruthless vengeance of a Biblical plague.

For now, practical matters dominate and are no less affected. This pandemic has redefined the risk:benefit balance of cardiopulmonary resuscitation. Where clinicians once believed "there is no harm trying," they realise that CPR offers little benefit to patients but brings significant risk to staff as they wait for the protective equipment that was promised in the UK and globally (doi:10.1136/bmj.m1423; doi:10.1136/bmj.m1367). As uncomfortable as it may seem, Zoë Frith and Gavin Perkins argue that not to offer CPR to patients with covid-19 is justifiable (doi:10.1136/bmj.m1387).

Adding to the scandals of unpreparedness and lack of personal protective equipment is the scandal of testing. Test, test, test is the mantra of the World Health Organization and other countries experienced in responding to epidemics. Test, case find, and isolate (doi:10.1136/bmj.m1284). But tests for healthcare workers are only now becoming available, and the UK's ambition of 100000 tests a day by the end of April sounds delusional, given the current logistical failings. Germany's relatively low case fatality rate is helped by an "early and high level of testing" (doi:10.1136/bmj.m1395). Testing for antibodies would be a "game changer," explain Nick Beeching and colleagues, if only tests were available and validated (doi:10. 1136/bmj.m1403).

Years since SARS, months since Wuhan, the NHS relies on the heroic professionalism and planning skills of its staff, and the self-control of the public (doi:10.1136/bmj.m1364; doi:10.1136/ bmj.m1408). Many health professionals, understandably in utter desperation, have spoken out about their working conditions and personal risks. But if you are brave enough to do so, you may be met with a further scandal: censorship and disciplining of staff (doi:10.1136/bmj.m1388). Other scandals are riding hard at us, such as people dying at home too scared to go to hospital or not receiving the care they need because of the focus on covid-19. The world turned upside down indeed.

For The BMSs extensive coverage of covid-19, including our regular podcasts, visit our online resource centre (bmj.com/coronavirus).

Published by the BMJ Publishing Group Limited. For permission to use (where not already granted under a licence) please go to http://group.bmj.com/group/rights-licensing/ permissions 